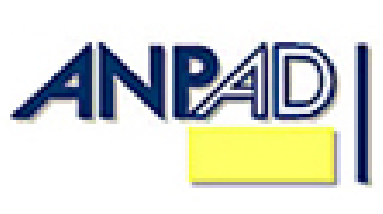
Available online at
http://www.anpad.org.br/bar
BAR, Rio de Janeiro, v. 12, n. 3, art. 5, pp. 309-323, July/Sept. 2015 http://dx.doi.org/10.1590/1807-7692bar2015150026

\title{
Methodological Reflections on Practice-Based Research in Organization Studies
}




\begin{abstract}
This article aims to discuss methodological possibilities for empirical research on practice-based studies. From the small number of publications on research and methodological procedures on the study of practices, the text makes a rescue of the philosophical assumptions of practice theories, so it can further bring the discussion of how they influence in the form of access to and analysis of empirical data. It is, therefore, a theoretical text that seeks to present general guidelines to foster the development of specific methods for practice-based studies as its main contribution. Further, it discusses ways of collecting and analyzing empirical data from the practice lens perspective.
\end{abstract}

Key words: practice-based research; methodology; practice theory; organization studies. 


\section{Introduction}

Practice-based studies or practice theories, are gaining prominence in the international academic production since the movement called Practice Turn from the 2000s (Miettinen, Samra-Fredericks, \& Yanow, 2009; Schatzki, 2001). The theme, though ancient, gained new dynamics through reinvigorated theoretical articulations and more dialogue among researchers from various practical approaches.

In this context, the practice theories regarding the definition of what is to be practical arises at the same time, as a possibility to investigate and discuss various topics related to organization studies. Despite being a polysemous area, topics which which stand out include learning and knowledge (Brown \& Duguid, 1991; Cook \& Yanow, 1993; Fenwick, Nerland, \& Jensen, 2012; Gherardi, 2001, 2006; Nicolini, Gherardi, \& Yanow, 2003; Strati, 2007), strategy-as-practice (Jarzabkowski, 2004; Whittington, 1996), education (Bispo, 2015; Davis, 2012; Gherardi, 2015; Landri, 2012), science and technology (Orlikowski, 2000, 2007; Suchman, Blomberg, Orr, \& Trigg, 1999).

This diversity of approaches on practice as well as the investigated research topics end up raising a discussion from the following question: what would be the most appropriate methodological possibilities to conduct a practice-based study? This question certainly makes room for debate on the subject. Talking about practice theories which leads to the determination that theoretical and conceptual polysemy must also be present, in diversity, the methodological possibilities for driving such a study.

Some authors have been collaborating in an attempt to build specific methods to account for an epistemology focused on practices. Therefore, it is possible to quote from Bourdieu (1977) with the idea of praxiology, Nicolini (2009a, 2009b, 2013) with the idea of shadowing, which is also supported by Gherardi (2012) and Czarniawska (2008), and Bispo and Godoy $(2012,2014)$ with ethnomethodology.

Thus, the main objective of this article ${ }^{(1)}$ is to discuss methodological possibilities for empirical research on practice-based studies. The main reasons given are: (a) the large number of studies that have been taking practices as a theoretical framework, such as strategy, organizational learning, education, nursing, technology, among others; (b) the need to contribute to the advancement of research in the practice field; (c) and the fact that the study of practice still needs more methodological discussions (Gherardi, 2012; Nicolini, 2013).

It is important to define, from this introduction, that this is not a proposal for a specific method to investigate practices, but an epistemic and methodological discussion on the foundation of this kind of research. It is also an effort to debate the ways of access to and analysis of data that are highlighted and likely to support future research methods propositions on practices. This is a key point since I am not interested in addressing a methodology for a specific theory of practice, but rather remind that practice in itself is considered by many authors (Gherardi, 2012; Nicolini; 2013; Santos \& Silveira, 2015) as an epistemology. Therefore, it is a previous or preparatory stage for conducting the empirical research itself; i.e., the epistemological viewpoint guides the strategies to access and analysis of empirical data.

In addition, my choice to carry out the proposed objective is, before conducting the empirical research itself, to rescue some philosophical assumptions of practice theories in the first part of the article in order to sustain the methodological possibilities that will be proposed and discussed in the second part of the text. Following is an open space for discussion of methodological limitations encountered and the possibilities of advancement of empirical research on practice-based studies. Final remarks will be presented seeking to bring a closure to this article from my point of view, as it is far from a consensual and consolidated solution. 


\section{Epistemological Aspects of Practice Theories}

Before starting the discussion on the epistemological aspects of practice theories, I think it would be appropriate to say that this article is not intended to present the history, settings, or the traditions of practice-based studies. This option is due to the large number of publications that have contributed to this effect already (Azevedo, 2013; Bispo, 2013; Gherardi, 2006, 2012; Nicolini, 2013; Nicolini et al., 2003; Reckwitz, 2002; Schatzki, 2001).

My goal at this point of the text is to rescue the epistemological assumptions that led to the constitution of the movement of practice-based studies as a theoretical body. Issues which are relevant to a discussion on methods of empirical research on practice can be raised from them.

According to Nicolini, Gherardi and Yanow (2003) the notion of practice to scholars of the Practice Turn in its philosophical essence, is influenced by four major areas of knowledge - in the Marxist tradition, phenomenology, symbolic interaction, and the legacy of Wittgenstein. These influences greatly contributed to the understanding of practices when considered in relation to phenomena such as: knowledge, meaning, human activity, power, language, organizations, and organizing.

Added to this, it is still possible to highlight several contributions to the historical and technological changes that take place, and are also issues of practice field for those who share them. In addition to this, I will still include the contributions of post-humanism due to the importance of nonhumans to understand practices (Gherardi \& Perrotta, 2014; Latour, 2005; Schatzki, 2001, 2003, 2010).

To redeem briefly the main ideas of these five traditions that philosophically support a big part of what has been built in the practice theories, beginning with Marxism. The notion of practice brings with it the idea that we only know facts and they are objects of our practice, so the thought and the world are always associated with human activity. Thus, thinking is just one of the human actions, the practice is composed by the union of our world's production with the result of this process. The practice is always the product of specific historical conditions resulting from previous practices that become our present practice. The process producing material also involves the creation of goods as the reproduction of society. The great contribution of this tradition, from the epistemological point of view, is to the effect that practice is an activity network in which knowing is not separate from doing (Gherardi 2006; Gherardi \& Perrotta, 2014; Nicolini et al., 2003).

In turn, regarding phenomenology contributions to practice studies (Practice Turn) it is possible to mention the everyday organizational life through human life-world and the avoidance of dualisms. Thus, activities such as work, learning, innovation, communication, negotiation, conflict of objectives, the interpretation of these same objectives, and their own history, are within a flow of existence as a practical endeavor. Therefore, they are part of human existence. Based on the Dasein concept of Heidegger (1996), which means being there or being-in-the-world, phenomenology states that there is no distinction between subject and object, both are part of a social and historical setting in which there are not dualisms. Both subject and object only make sense as a construction of meaning that cannot be understood in isolation (Nicolini, 2013; Nicolini et al., 2003).

With regard to symbolic interactionism, this also makes a significant contribution to the understanding of practices, to highlight interactions between individuals, and between individuals and objects; so that all knowledge can be accessed through interaction. According to Blumer (1986), the movement of symbolic interactionism is built on three premises: the first one states that human beings act on facts based on the meaning they have for the groups to which they belong.

These facts include everything that humans can notice as physical objects; i.e., other human beings, individual categories such as friends or enemies, institutions, ideals, other activities, and situations encountered in their daily lives. The second shows that the significance of facts or drift arises from social interaction between a member and another. Finally, the third assumption states that the 
meaning of facts is proper and modified by an interpretative process used by people in order to deal with the events they face.

In short, symbolic interactionism indicates that meanings that facts have for humans are central in its conduct. Thus, human interaction is mediated by language and the use of symbols for the interpretation of facts; this is what provides access to the meaning of others' actions in the lived context (Blumer, 1986).

Another thought that contributes to the understanding of practices is the legacy of Wittgenstein, which brings the importance of the elements of language and meaning in their relationship with their own practice through language games. For Wittgenstein language promotes social practice and allows the construction of meaning and sense.

Thus, participation in practice means to be part of the language game, and appropriating it. Language is not just a means of conveying information, but also an action that builds meaning and practice itself. These ideas show that a practical understanding is always tacit, a silent game, not translated in words (Nicolini et al., 2003; Schatzki, 1996; Wittgenstein, 1953).

Post-humanism (Latour, 2005, 2013; Schatzki, 2001, 2006) as an epistemological position, tries to counter the role of the human against the non-human. Critical approaches in the social world and everyday life are understood only by human action, ignoring or taking non-humans as insignificant and with a non-agency status. The name post-humanism, despite its strageness, is a philosophical movement that does not advocate the end of humanity itself or reduce its importance in the construction of the social.

It only leaves room for social phenomena, including practices, which are understood as a relationship between humans and non-humans. Thus, objects and artifacts also have agency in social construction. As Latour (2005) said, this is not to seek a balance or agency of symmetry between human and nonhuman, but the pursuit of understanding of both as modes of existence.

As a way to position what practice is in this article, I will begin with Gherardi's (2006) definition: "practice as a mode, relatively stable in time and socially recognized, of ordering heterogeneous items into a coherent set" (p. 34). It is important to notice that heterogeneous in this quote includes humans and non-humans. From this definition, I understand practice as a way of organizing humans, nonhumans and the activities produced by them into a coherent, symbolic and meaningful set. In other words, we construct organizations around practices.

Yet according to Gherardi (2009), the label of communities of practice in reality may be called practice of a community because practices determine organizations and not the opposite, as usually conceived in management. It is one of the reasons that many authors claim an epistemology of practice; i.e., a specific way to produce knowledge about organizations and their phenomena. In addition, it is important to say that a definition is only a way to prepare readers for an issue but one that carries many limitations.

After the presentation of the main philosophical influences from practical theories, I discuss what the consequences of these influences are, what I will call here the epistemological assumptions of theories of practice or practice-based studies. However, first we must recall that practice theories are a kind of umbrella for a set of theories and approaches, which means that each has interdependence with respect to another. So what will be presented are the assumptions that they share with each other and that enable recognizing them as practice theories.

Given what I just mentioned, it is possible to say that all practical theories seek to demonstrate the importance of activity, performance, and work in creation and perpetuation of all aspects of social life. Thus, practice-based studies have focused on the procedural and tend to see the world as continuous achievements and routinized, in search of aspects that demonstrate or explain the most durable phenomena of social life. Among which we can mention institutions, organizations, family, and others 
that are representations of how activities are performed (Gherardi, 2012; Nicolini, 2013; Schatzki, 2001).

This stands out as the first assumption of practice-based studies; i.e., practice itself as the unit of analysis to understand organizational phenomena. Through this, it becomes possible to access and understand action, agency, and the agents or practitioners.

In other words, practice theories offer a chance to reinterpret organizational phenomena, for example, by suggesting that the object of research should be the activities of management and entrepreneurship, and not the managers and entrepreneurs (Nicolini, 2013). Latour (2013) highlights this epistemological position when he says that the object in the scope of practice is the organizational and not the organization.

A second assumption is that practice theories go beyond describing what people do. The practices are, in fact, the creation of meaning, identity formation, and ordering of activities produced. In a way, practice theories take a performative perspective in order to offer a new look at the social world that goes beyond saying what people do, which is something it has in common with the positivist and rationalist views of social sciences (Nicolini , 2013).

It also considers cognition and sense-making as emerging practices of an organization. Thus, a practice-based view is an alternative to cognitive perspectives, which try to explain organizational behavior as a result of the individual's mind. The perspective of practice embraces the idea of the creation of meaning, but rejects that this creation is an intangible mental process, a form of symbolic exchange or abstract coordinated process based on some kind of a communicative process.

In this sense, the creation of meaning and knowing are concrete and identified through the artifacts and objects, discursive activity, body, habits, and concerns that are part of organizational members' lives (Gherardi, 2006; Nicolini, 2013; Reckwitz, 2002; Schatzki, 2001).

Given the above, one can say that practice theories assume discursive practices to be relevant for construction and reproduction of all organizational and social things, however resist the idea that language and discourse alone can explain all phenomena of organizational life. The approach of practices suggests that we need theories that give account to the heterogeneous nature of the world we live in, which includes considering objects and materials, in other words, non-humans (Latour, 2013; Nicolini, 2013; Schatzki, 2003, 2010).

Another assumption is that practice theories suggest that organizations and institutions are constructed and modified because of material and discursive work. Thus, the focus is on dynamic procedural understanding of both. In this context, consider that organizational relationships are composed of sets or practices networks, while rejecting the division of social phenomena in levels; for example, micro and macro, or individual and organizational, etc. (Gherardi, 2006, 2012; Gherardi \& Perrotta, 2014; Nicolini, 2013).

Regarding all these epistemological aspects of practice, Nicolini (2013) states that practices may be understood as an idiom/epistemology which

practice idiom is therefore much more than a theoretical lens that one can adopt in response to the latest academic fashion or can retrofit to the usual way of doing research. Rather, the practice idiom is an ontological choice, a recognition of the primacy of practice in social matters, as well as the adoption of the idea that practices (in one way or another) are fundamental to the production, reproduction, and transformation of social and organizational matters (Nicolini, 2013, pp. 13-14).

The discussion here is very relevant to the empirical conducting of research from practice theories, since these assumptions end up as flags in the planning of research, that is, in strategies of access to (collection/construction) and analysis of empirical data. According to Llewellyn (2008), practices have to be understood and studied from an analytical point of view rather than only in a descriptive form. 
Therefore, the epistemological aspects of practice theories imply preliminary evaluation of the choice of method and ways of conducting technical access and data analysis. This observation calls attention to details ranging from the choice of methods and techniques, to how to use them considering limits and potential according to practice epistemology.

\section{The Research on Practice and the Practice of Research}

Currently, the literature is limited in practice-based studies with respect to proposing specific methods for conducting empirical research. Still, some authors have presented some methodological possibilities based on praxiology (Bourdieu 1977), shadowing (Czarniawska, 2008; Gherardi, 2012; Nicolini, 2009b, 2013) and interview to the double (Nicolini, 2009a). The Bourdieu praxiology (1977) is a theoretical knowledge in the social world, from the idea of practice, with the intention that praxiology provides wider and deeper explanations of complex social processes. Praxiology means to stop looking at the operatum opus (product) and work towards understanding the modus operandi (process). In other words, is to establish a dialectical process between agent and structure in which the author proposes this mediation through the concept of habitus. Thus, it is possible to say that praxiology appears more as a methodological design instead of a structured method itself.

The shadowing proposal, in short, is based on the idea that the researcher must follow the researched practice by watching the practitioners, in order to observe it and understand its dynamics, so they can be able to describe and analyze it. The analysis seeks essentially see the practice as an insider and an outsider. That is, if they see the practice inside, it gives the researcher the condition to understand it from the logic of practitioners; while still seeing the practice from an impartial outside. This helps the researcher to fully capture features and activities that are not perceived by practitioners as well as see it more broadly (Czarniawska, 2008; Gherardi, 2012; Nicolini, 2009b, 2013).

The interview to the double is a methodological strategy of seeking to know the practice from the researcher's learning process about it, with a kind of practitioner who is invited to play the role of researcher mentor, as if he/she was a newcomer to a particular group. Thus, the researcher follows the activities of the practitioner, at first, he/she will be describing and teaching the researcher how to develop and behave in front of certain constituent activities of the practice.

Then the researcher takes the place of the practitioner in the implementation of activities and while supervised by him/her, he/she performs the practitioner's activities in order to genuinely experience the practice and better describe and analyze it (Nicolini, 2009b). It is possible to notice that both the shadowing and the interview to the double are not mutually exclusive and can be combined.

Even with everything said above, in general the empirical research about practices has been developed within a primarily qualitative scope, in which there is a great diversity of methods, especially including ethnographic, grounded theory, case studies, and ethnomethodology. However, it is important to notice that the researcher in this kind of research is focusing on a practice (or a bundle of practices) and the organization around it. Methodologically, it is crucial understand that the concepts of practice and organization are different from routine and company respectively. It means that an organization from this point of view could be present in many companies because a practice can be present in different places or organizations. Therefore, that is why philosophical assumptions are so important to construct a method and a methodology in practice-based research.

In this context, empirical research on practice requires caution on the part of the researcher in relation to access to data and respective action analysis, that it is either making use of the proposed shadowing, interview to the double and praxiology, or other more traditional qualitative methods. Right now the philosophical basis (ontological and epistemological) from practical theories must be redeemed and considered by the researcher, so each technique can contribute to initially set goals so empirical research can be completed. 
As a contribution to this point, I present some considerations about access techniques to empirical data, as well as its analysis. Remember that my purpose here is not to present a method that is ready for practices analysis; but help researchers reflect on their research strategies in order to foster the development of their own methods, or even properly employ existing ones within what is proposed in practice-based studies.

The first, and most important, point is that when proposing to conduct a research from the approach of practices, the unit of analysis is the practice. Therefore, you lose the sense of the research proposal of a phenomenon with the practice lens when the practice is not the main analysis point (Gherardi, 2012; Nicolini, 2013; Schatzki, 2001). In addition, the creation of other categories of analysis to conduct a study on practices is a mistake that should be avoided.

Based on this, the following question arises: How do I identify and analyze one or more practice? This should be the main question that many researchers ask, and with some guidance on immersion into the research field, it helps to answer the question.

The first important thing in order to identify a practice is to assume that it is something that happens but not as a priori practice in the sense of theory testing. It means that to identify a practice it is necessary to observe it and understand its dynamics (process). This is the main goal of the researcher: to understand, describe, analyze and explain why things are the way they are through the practice lens. In so doing, I will briefly discuss some aspects about the techniques of observation, interviews, documents, recording, and transcription of material captured in the field in order to contribute how to identify a practice.

Starting with aspects related to observation, I also make evident that in the view of many authors (Bispo \& Godoy, 2014; Czarniawska, 2008; Gherardi, 2012; Nicolini, 2009a, 2009b, 2013), it represents the major technical access to empirical data regarding a practice-based research. Observation in its various forms has contributed effectively in studies of practice because it allows the researcher to access the field and check while the constituent activities of practice are running or going in their naturalistic way.

Therefore, to observe one or more practices becomes the main feature of the researcher, so he/she can understand the dynamics and the characteristics they possess. Since observation having many possibilities, including ethnographic, it offers circumstances where the researcher can experience the practice in order to be, at the same time, an insider and an outsider. This process of zooming in and zooming out (Gherardi, 2012; Nicolini, 2009b, 2013) helps researchers best define the studied practice, better knowing its dynamics and the actors involved, both human and non-human. The main challenge is to know the practice as an insider to catch the meanings, accountability and the way to do the practice the same way as the practice members do it. On the other hand, it is necessary to see the same practice as an outsider to be able to analyze it in a different way that the members can, in terms of the nonreflexive part of the practice.

Interviews can also contribute to research in practice-based research; however, they present important limitations when used in isolation, or as a protagonist technique in the research to be developed. It is important to say that despite the fact that interview techniques are the main strategies to access data in qualitative studies (Merriam, 2009; Roulston \& Shelton, 2015), in the case of practicebased studies this role should be prudent.

Interviews capture, in general, the speeches, the memories, and the knowledge people carry with them, or have about a certain topic or subject. Therefore, when the researcher wants to confirm, confront, or even know historical aspects concerning some practice; these techniques can be useful since the researcher cannot always access this data in another way. However, interviews alone cannot meet certain conditions to access some relevant aspects in the research of practices.

The first limitation is because we are unable to access the dynamics of a practice from the discourse of the other(s), considering that it will be a reporting of something passed through and that it is subject to memory lapses, distortions of the facts, possibility of omission, and even the lack of veracity 
of some data. In addition, as discussed earlier in this article, although the speeches and discourses are integral and relevant in the constitution of practices, these alone are not enough to explain all of the dynamics and complexity of reality itself. Some aesthetics (Strati, 1992) about data and ongoing process are harmed with the exclusive adoption of interviews.

Another important aspect regarding interviews is a certain degree of dogmatism created in the form of treatment of the data generated by them. It has become almost a rule saying that interviews were recorded and transcribed, as if that was a guaranteed best way to conduct interviews for all types of qualitative research.

My question is: As good as the recording and the transcript will be, is there no significant loss of aesthetic data, for example? How are the non-humans in a practice captured in that context by only analyzing speeches? Or, how are the dynamics of a practice captured only with the interviewees' discourse? And what do they not know, or do not realize they know, and do not include in the interviews?

Thus, the exclusive or extensive use of interviews should be considered limitations to the research on practices. Interviews are useful as a mean of triangulation of data and supplementary information that is not accessible to observations. It is also important to say that when interviews are recorded and analyzed as a movie and not transcription it helps to significantly reduce data loss. Finally, the number of interviews in practice-based studies can vary greatly, depending on the purpose of the research.

Another practical way of research is through documents, whether produced for research or not. They can contribute to the understanding of how some practices materialize and can express aspects that were unnoticed during observation. In relation to documents produced for research, photos and films help rescue the research context of observation and also allow repeated access to data and facilitate analysis. They are also useful in analysis in that they can materialize aspects of practice that are very subjective and difficult to verbalize. So they are welcome throughout the text to help the reader understand the studied practice.

Documents that have not been produced for research purposes, such as manuals, reports, projects, emails, among others can contribute to help the researcher see how some practices materialize and how they influence the practice itself. These sorts of documents are good resources of complementary data and useful as a mean of triangulation and supplementary information.

Some considerations on the analysis of the data accessed in the field are necessary. One is to say that a practice is a way to describe, understand, and analyze a phenomenon that is called practice. So when a researcher assigns a name to a set of activities, that is what we are calling practice; i.e., a way of organizing. However, this does not mean that the identified practice is separated from other practices and might not even be part of a larger practice in which it is inserted.

Another important point is that practices have a direct influence on the way the researchers of this approach see and understand organizations. For scholars of practice, organizations are formed by practices and determined as such (Czarniawska, 2013; Latour, 2005, 2013). Therefore, when analyzing a practice, it is essential to have defined an ontological position on organizations, and understand that a practice can cross two or more institutions and / or companies that are currently conventionally called organizations. This observation is important because it has generated a lot of confusion and analytical conflicts during this phase of the research.

To illustrate this situation I will use the example of corrupt practices. A study that is investigating corruption as a practice cannot be limited to making it into only an institution, without the risk of not capturing all nuances. Furthermore, it is important to realize that corruption is a form of organization, which is not similar to what is called organization in the common sense.

When considering all presented aspects, practice-based studies require specific care for conduction. Therefore, it is up to us to emphasize that this is not just the use of a theoretical approach or new epistemology as an academic fad (Nicolini, 2013). By opting for practice theories, the researcher 
must meet the methodological developments needed to conduct research in order to avoid creating an academic Frankenstein.

In this sense, the analyzing process of empirical data is a step that the researcher should first reflect about his/her experience in the field in order to identify the key activities of practice, including non-humans. In other words, this first reflection is the moment to establish the draft of a practice, such as guidelines of its constitution.

After that, in order to better understand, describe and explain the practice, it is necessary to go through the collected material and organize them inside the set of activities identified and which constitute the practice together; i.e., which material will help me analyze each activity that forms the practice. It is important to clearly describe each activity and how they constitute the main practice. In this moment, you will have a first constitution and description of the practice as an insider, or "a mode, relatively stable in time and socially recognized, of ordering heterogeneous items into a coherent set" (Gherardi, 2006, p. 34).

To go in depth to explain the practice, it is necessary to conduct a second analysis process considering the practice as a whole. At this moment the data have to be revisited, researching the practice as an organizing way of humans, non-humans and the activities produced by them in a coherent, symbolic and meaningful set, as an outsider. Figure 1 illustrates this process.

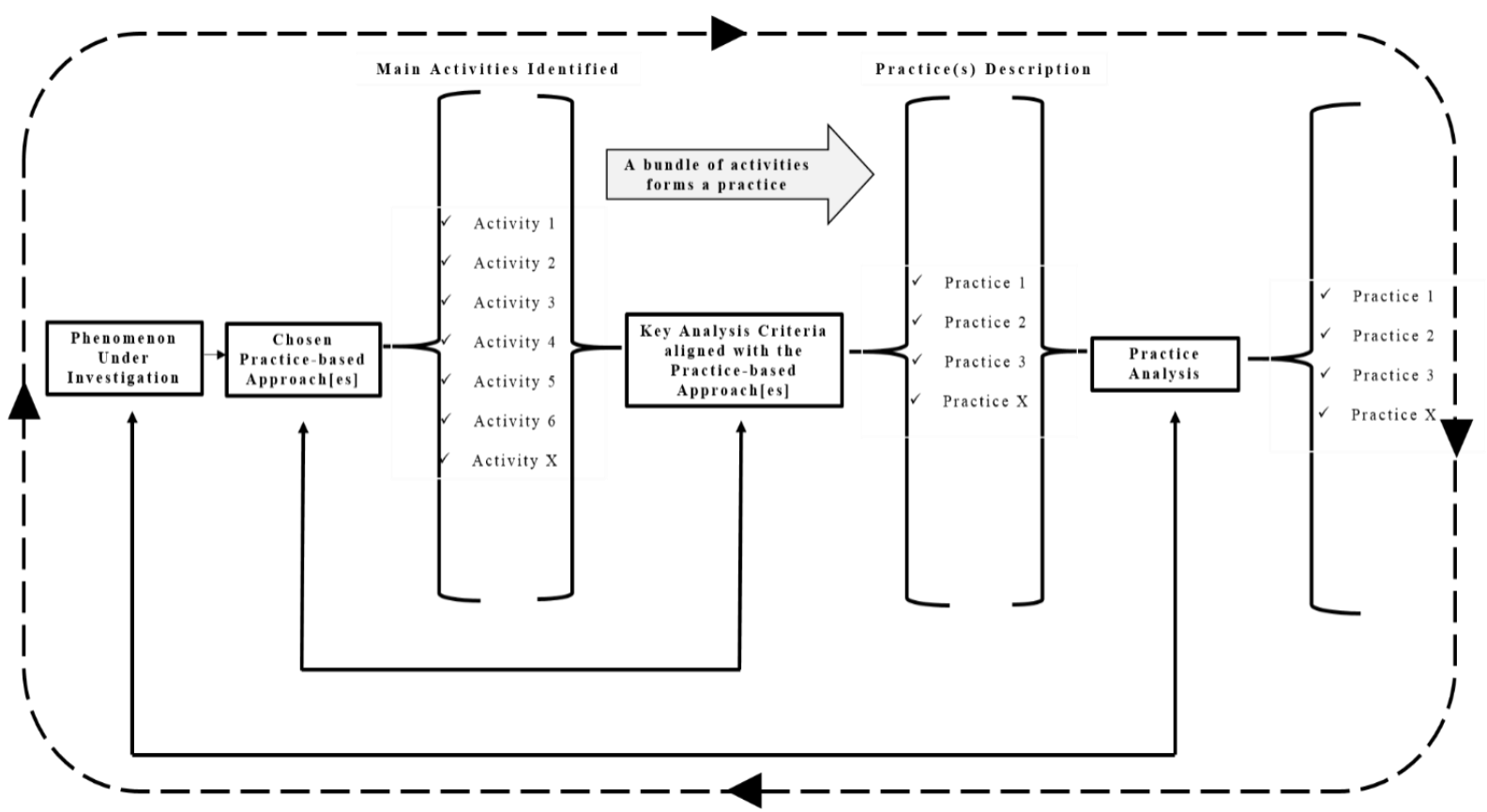

Figure 1. Practice-based Data Analysis Process Framework Source: Author

The figure is a simplified framework to illustrate my point of view of how to analyze data from a practice-based approach perspective. It has not intended to be a generalized framework, but it helps to reflect upon a process of data analysis. It is also important to notice that this proposal respects the idiosyncrasies of each practice-based approach by calling attention to the chosen practice-based approach[es] which will determine the analysis criteria of each approach. I would like to call attention to a specific topic that is the Cultural Historical Activity Theory (CHAT) approach.

The term activity, especially due to Marx's influence, has the status of practice for these scholars. Thus, according to my proposed framework it is necessary to understand that for these scholars a bundle of praxis forms an activity. This is an example of label situation that reinforces the existence of an umbrella, which has many approaches that have to be respected in their own characteristics and do not offer the opportunity to conduct a unique practice-based research. 
However, at the time, some authors (Gherardi, 2012; Nicolini, 2013) state that it is possible and positive to use two or more practice-based approaches combined in order to investigate and understand many sorts of social and organizational phenomena. In this case, the existence of sharing epistemological roots opens the possibility to do so.

Another methodological observation that I would like to make is for those scholars that use the Strategy as Practice approach. Many studies that deal with strategy from a practice-based view presents two main problems from my point of view. The first is that many authors do not have in mind a clear conception of what is practice and this is apparent in their articles. The second is that they usually focus on managers' rationalist idea of strategy. These criticisms has been mentioned before by authors such as Carter, Clegg and Kornberger (2008), and Nicolini (2013).

The review of practice-based approaches leads attention to how practice research does not follow individuals but how practices and strategy have a lot of practitioners beyond the managers and nonhuman elements that have to be present in this sort of study. In so doing, it is necessary to pay close attention to how the case-study method is common in this sort of research. When a case study is carried out with strong bases on interviews, it shows an important limitation as I discussed before. In addition, it is also important to keep a concept of practice in mind in order to identify the unit of analysis of the study carried out and its data analysis.

\section{Final Remarks}

This article aims to discuss methodological possibilities for empirical practice-based research. From the scientific gap on this issue and the increase of publications that have used the practice theories, I realized the need to write about it in an attempt to engage with peers and at the same time, seek to collaborate with those who are proposing to start their research on this approach.

The initial discussion point came from the redemption of the philosophical assumptions underlying the practice-based studies. This option had two goals, one relating to the redemption of which helped to form what we now call the practice theories; and the second, to reinforce the need for clear epistemological foundations for conducting scientific research. So I can say that epistemology takes the researcher to the method and not the opposite.

Following the epistemological considerations, I opened the space to discuss how research practices invite researchers to create their own methods in the conduct of their studies, as well as pay attention to how to employ known methods of research to adopt practice-based studies. So at this time, I want to open the space to debate the unrest that I carry with the automatism that exists in many qualitative studies.

Criticism is, more specifically, the creation of a rule that a qualitative research is always preferably conducted by interviewing techniques that should be recorded, transcribed, and analyzed using content or discourse analysis. This situation has imposed a certain modus opendi in qualitative research, and it inhibits researchers from doing differently or even expanding their perception of what qualitative research is.

It must be said that research is a process of knowledge production which invites and demands that the researcher develop the best way (methodology) for achievement of their research goals. This means that to satisfactorily achieve the research, the researcher needs to fit it into any of the existing squares/boxes (methods). The use of existing methods is appropriate when it fully meets what you want from the research. Otherwise, the creation of new methods is always welcome.

This criticism is not a way to disprove or discredit the research that has been conducted and thus contributed to the production of scientific knowledge, but to draw attention to the practice-based studies that require a slightly different methodology from the criticized one. Especially in the forms of access 
to and analyzation of empirical data, and being open to new methodological contributions to the field of practice-based research.

In other words, I am calling attention to the difference between rigor and rigidity. Rigor is related to consistency in the conduct of research within the scientific assumptions, including the philosophical, that it is proposed to research in order to identify an alignment between philosophical, theoretical, methodological, and analysis of results.

On the other hand, rigidity leads many researchers to think that all research should be conducted in a unique way within a pre-established, inflexible scope; so the method overrides the goals and philosophical assumptions of the research. That is, the method is a mean and not the end of the scientific research.

Therefore, it is also important to say that research with access techniques or collecting of equal data such as, interviews, does not require that they be conducted in the same way in all contexts. This is what happens in practice-based studies.

At last, I would like to share that my recognition on this topic and its discussion does not end here, on the contrary. I hope to advance the quality of research on practices to consolidate the approach and so we can distance ourselves from any academic fad, I also think it can open space for criticism and other possibilities. In addition, I agree that we are just at the beginning of the debate and we will have many other rounds to come.

\section{Acknowledgments}

The author would like to thank Paolo Landri from CNR (Italy), Dario Minervini, and Fabio Corbisiero from Naples University due to their contributions in a preliminary version of the paper presented at that University in April 2015.

\section{Note}

${ }^{1}$ Article funded by The Brazilian National Council for Scientific and Technological Development (CNPq).

\section{References}

Azevedo, D. (2013). Aprendizagem organizacional e epistemologia da prática: um balanço de percurso e repercussões. Revista Interdisciplinar de Gestão Social, 2(1), 35-55. Retrieved from http://www.rigs.ufba.br/pdfs/RIGS_v2_n1_art2.pdf

Bispo, M. S. de (2013). Estudos baseados em prática: conceitos, história e perspectivas. Revista Interdisciplinar de Gestão Social, 2(1), 13-33. Retrieved from http://www.rigs.ufba.br/pdfs/RIGS_v2_n1_art1.pdf

Bispo, M. S. de (2015). E-learning as organizing practice in higher education. In M. Kennedy, S. Billett, S. Gherardi, \& L. Grealish (Eds.), Practice-based learning in higher education: jostling cultures (pp. 111-126). Netherlands: Springer International.

Bispo, M. S. de, \& Godoy, A. S. (2012). A etnometodologia enquanto caminho teórico-metodológico para a investigação da aprendizagem nas organizações. Revista de Administração Contemporânea, 16(5), 684-704. Retrieved from http://www.scielo.br/pdf/rac/v16n5/v16n5a04.pdf. doi: 10.1590/S1415-65552012000500004 
Bispo, M. S. de, \& Godoy, A. S. (2014). Etnometodologia: uma proposta para pesquisa em estudos organizacionais. Revista de Administração da Unimep, 12(2), 108-135. doi: 10.15600/16795350/rau.v12n2p108-135

Blumer, H. (1986). Symbolic interactionism: perspective and method. California: University of California Press.

Bourdieu, P. (1977). Outline of a theory of practice. Cambridge: Cambridge Press.

Brown, J. S., \& Duguid, P. (1991). Organizational learning and communities-of-practice: toward a unified view of working, learning and innovating. Organization Science, 2(1), 40-57. doi: 10.1287/orsc. 2.1 .40

Carter, C., Clegg, S. R., \& Kornberger, M. (2008). Strategy as practice? Strategic Organization, 6(1), 83-99. doi: 10.1177/1476127007087154

Cook, S. D. N., \& Yanow, D. (1993). Culture and organizational learning. Journal of Management Inquiry, 2(4), 373-391. doi: 10.1177/105649269324010

Czarniawska, B. (2008). Organizing: how to study it and how to write about it. Qualitative Research in Organizations and Management: an International Journal, 3(1), 04-20. doi: $10.1108 / 17465640810870364$

Czarniawska, B. (2013). Organizations as obstacles to organizing. In D. Robichaud \& F. Cooren (Eds.), Organization and organizing: materiality, agency, and discourse (pp. 3-22). New York: Routledge.

Davis, C. (2012). Practice as complexity: encounters with management education in the public sector. In P. Hager, A. Lee, \& A. Reich (Eds.), Practice learning and change: practice-theory perspectives on professional learning (pp. 133-150). New York: Springer.

Fenwick, T., Nerland, M., \& Jensen, K. (2012). Sociomaterial approaches to conceptualising professional learning, knowledge and practice. Journal of Education and Work, 25(1), 1-13. doi: $10.1080 / 13639080.2012 .644901$

Gherardi, S. (2001). From organizational learning to practice-based knowing. Human Relations, 54(1), 131-139. doi: 10.1177/0018726701541016

Gherardi, S. (2006). Organizational knowledge: the texture of workplace learning. Oxford: Blackwell Publishing.

Gherardi, S. (2009). Practice? It's a matter of taste! Management Learning, 40(5), 535-550. doi: $10.1177 / 1350507609340812$

Gherardi, S. (2012). How to conduct a practice-based study: problems and methods. Cheltenham: Edward Elgar.

Gherardi, S. (2015). Conclusions: towards an understanding of education as a social practice. In M. Kennedy, S. Billett, S. Gherardi, \& L. Grealish (Eds.), Practice-based learning in higher education: jostling cultures (pp. 173-182). Netherlands: Springer International.

Gherardi, S., \& Perrota, M. (2014). Between the hand and the head: How things get done, and how in doing the ways of doing are discovered. Qualitative Research in Organizations and Management: An International Journal, 9(2), 134-150. doi: 10.1108/QROM-06-2012-1079

Heidegger, M. (1996). Being and time. Albany: SUNY Press. 
Jarzabkowski, P. (2004). Strategy as practice: recursiveness, adaptation and practices-in-use. Organization Studies, 25(4), 529-560. doi: 10.1177/0170840604040675

Landri, P. (2012). A re-turn to practice- practice-based studies of education. In P. Hager, A. Lee, \& A. Reich (Eds.), Practice learning and change: practice-theory perspectives on professional learning (pp. 85-102). New York: Springer.

Latour, B. (2005). Reassembling the social: an introduction to actor-network-theory. Oxford: Oxford University Press.

Latour, B. (2013). "What's the story?" Organizing as a mode of existence. In D. Robichaud \& F. Cooren (Eds.), Organization and organizing: materiality, agency, and discourse (pp. 37-51). New York: Routledge.

Llewellyn, N. (2008). Organization in actual episodes of work: Harvey Sacks and organization studies. Organization Studies, 29(5), 763-791. doi: 10.1177/0170840608088766

Merriam, S. B. (2009). Qualitative research: a guide to design and implementation. New York: JosseyBass.

Miettinen, R., Samra-Fredericks, D., \& Yanow, D. (2009). Re-turn to practice: an introductory essay. Organization Studies, 30(12), 1309-1327. doi: 10.1177/0170840609349860

Nicolini, D. (2009a). Articulating practice through the interview to the double. Management Learning, 40(2), 195-212. doi: 10.1177/1350507608101230

Nicolini, D. (2009b). Zooming in and out: practices by switching theoretical lenses and trailing connections. Organizations Studies, 30(12), 1391-1418. doi: 10.1177/0170840609349875

Nicolini, D. (2013). Practice theory, work, \& organization: an introduction. Oxford: Oxford University Press.

Nicolini, D., Gherardi, S., \& Yanow, D. (2003). Knowing in organizations: a practice-based approach. New York: M. E. Sharpe.

Orlikowski, W. J. (2000). Using technologies and constituting structures: a practice lens for studying technology in organizations. Organization Science, 11(4), 404-428. doi: 10.1287/orsc.11.4.404.14600

Orlikowski, W. J. (2007). Socialmaterial practices: exploring technology at work. Organization Studies, 28(9), 1435-1448. doi: 10.1177/0170840607081138

Reckwitz, A. (2002). Toward a theory of social practices: a development in culturalist theorizing. European Journal of Social Theory, 5(2), 243-263. doi: 10.1177/13684310222225432

Roulston, K., \& Shelton, S. A. (2015). Reconceptualizing bias in teaching qualitative research methods. Qualitative Inquiry, 21(4), 332-342. doi: 10.1177/1077800414563803

Santos, L. L. S., \& Silveira, R. A. (2015). Por uma epistemologia das práticas organizacionais: a contribuição de Theodore Schatzki. Organizações \& Sociedade, 22(72), 79-98. Retrieved from http://www.scielo.br/pdf/osoc/v22n72/1413-585X-osoc-22-72-0079.pdf. doi: 10.1590/19849230724

Schatzki, T. R. (1996). Social practices: a wittgensteinian approach to human activity and the social. Cambridge: Cambridge University Press.

Schatzki, T. R. (2001). Introduction: practice theory. In T. R. Schatzki, K. Knorr Cetina, \& E. von Savigny (Eds.), The practice turn in contemporary theory (pp. 1-14). New York: Routledge. 
Schatzki, T. R. (2003). A new societist social ontology. Philosophy of the Social Sciences, 33(2), 174202. doi: $10.1177 / 0048393103033002002$

Schatzki, T. R. (2010). Materiality and social life. Nature and Culture, 5(2), 123-149. doi: $10.3167 / \mathrm{nc} .2010 .050202$

Strati, A. (1992). Aesthetics understanding of organizational life. Academy of Management Review 17(3), 568-581. doi: 10.2307/258723

Strati, A. (2007). Sensible knowledge and practice-based learning. Management Learning, 38(1), 6177. doi: $10.1177 / 1350507607073023$

Suchman, L., Blomberg, J., Orr, J. E., \& Trigg, R. (1999). Reconstructing technologies as social practice. American Behavioral Scientist, 43(3), 392-408. doi: 10.1177/00027649921955335

Whittington, R. (1996). Strategy as practice. Long Range Planning, 29(5), 731-735. doi: 10.1016/00246301(96)00068-4

Wittgenstein, L. (1953). Philosophical investigations. Oxford: Blackwell Publishing.

\section{Author's Profile}

Marcelo de Souza Bispo

UFPB/CCSA, Campus I - CCSA, 58051-900, João Pessoa, PB, Brazil. E-mail address: marcelodesouzabispo@ gmail.com 